\title{
Responsibility in an Era of Modern Technology and Nihilism. Part 2. Inter-Connection and Implications of the Two Notions of Responsibility in Jonas
}

ERNST WOLFF University of Pretoria

\begin{abstract}
This essay aims at clarifying the content of Jonas's philosophy of responsibility. First, an analysis is given of the connection between nihilism and modern technology. Jonas's contribution to the problem of ethics in this context is prepared by an interpretation of the way in which fear and the myth respectively function as motivations for his work. This paves the way to a reconsideration of the content of Jonas's philosophy, whereby two notions of responsibility should be identified: (1) responsibility as ethicity and (2) responsibility as foundational rule. With this distinction a number of problematic issues associated with his ethics of responsibility can be clarified.

RÉSUMÉ: Cet article vise à clarifier le contenu de la philosophie de la responsabilité de Hans Jonas. L'article commence par une analyse du rapport entre le nihilisme et la technique moderne. La contribution de Jonas sur cette question éthique doit être située par une interprétation de la façon dont la peur et le mythe motivent son travail. Ainsi s'ouvre une reconsidération du contenu de la philosophie de Jonas : deux notions de responsabilité peuvent être distinguées : (1) la responsabilité comme éthicité et (2) la responsabilité comme règle fondatrice. Cette distinction permet de clarifier un nombre de dilemmes associés à son éthique de la responsabilité.
\end{abstract}

Dialogue 48 (2009), 841-866.

(C) Canadian Philosophical Association/Association canadienne de philosophie, 2009 doi:10.1017/S0012217309990448 


\section{Introduction: Nihilism and Modern Technology}

In the introduction to Part 1 of this essay, ${ }^{1}$ I presented Jonas's philosophical problem in the following terms: How does one justify ethics in the face of the historically unprecedented developments in the technical extension of the human I can, and the contemporaneous explosion of contingent, culturally specific productions of meaning that are likewise indebted to the multifarious manifestations of the human I can? Although one could distinguish between the problem of nihilism and the vacuum of orientation in respect of the new technological condition, the two are intimately linked in the human agent. Therefore, if one is capable of giving some sort of orientation in ethics - as has been suggested in the first essay by means of Jonas's myth - technics is not merely a special domain of application of ethics; in fact, technics is not even primarily this. The principle of ethics itself is the principle called "responsibility," in as far as we can ask the question of what the essence of ethics in the "technological civilization" is. That is why the ambition of Jonas's reflection on ethics is not to apply already existing ethics to a new situation, but rather to understand first of all how the new situation has changed the very nature of ethics. This new situation is modernity - an epoch that is indissolubly linked to technological progress. ${ }^{2}$ The modern technological civilization is therefore not only a specific domain that is relevant for Jonas's ethics, it is the broadest context that calls for this new ethics. Furthermore, the same modernity has given birth simultaneously to the modern technical situation and the crisis of ethics that has been called the death of God. The answer to the question of how to live after the death of God is the same as the answer to the question of how to live in the technological civilization.

This close link between the technical and ethical situation has not always existed in the history of humanity. It is only since the dawn of modernity that somebody could declare that we "must, however, reflect on it [on technics], so that we don't turn it by thoughtlessness into our self-prepared fate" (WpE 26). The specificity of modernity resides in the fact that it is founded on an untenable premise - it is untenable because it is possible to show by the very means that issue from modernity that the premise is false. This premise is "that there can be limitless progress, because there is always something new and better to be found" (original emphasis) (TME 24). The emergence of this premise has been made possible by "an underlying and well-founded theoretical view of the nature of things and of the knowledge of them" (TME 25). At the core of modernity is a vision of the non-human world (I have already shown that this vision has induced the idea of the death of God and the concomitant problems for ethics). It is a vision of nature, as object of knowledge, which delivers itself to an apparently never-ending further exploration (TME 26). However, when "technological art therefore follows in the steps of natural science, then it too acquires from this source that potential of endlessness for its progressive innovation" (TME 27). In order for this vision of the world to gain ever-increasing 
sophistication, it has to be allied with technology. In fact, science needs technology as much as technology needs science, in view of the progress of both. It is thus that a relation of mutual feedback between theory and practice emerges in which the distinction between the two becomes blurred (TME 27, 29). Theory, which was once the road travelled to a fuller life, has become in modernity first and foremost a knowledge of things in order to change them (PL 194-195). This implies, practically speaking, that science has become technical, in that it is put to the service of common interests and needs. Technology, which was once the domain of the means to human ends, has come to be regarded as the telos of human existence, or even as the highest good of humanity (TME 30). Its development has become the de facto "vocation" of humankind (PV 31).

Whereas pre-modern technology tended to be a possession and a condition (TME 16) in which the slow changes had nothing to do with a socially institutionalized strive for progress (cf. TME 17-18), modern technics has become a fate (TME 21) of progress in which every new success becomes an occasion for further progress (TME 19). Often this progress is the result of technical answers to problems created by technical progress itself, such as competition and demographic growth (TME 22). Jonas's favourite examples of where this leads to is the threat of the destruction of the environment and the possible nuclear destruction of Earth, and the manipulation of the ethical agent through gene technology (see, for instance, the introduction to PE and TME, PV ch1). In this way, the premise of the modern technological age "that there can be limitless progress, because there is always something new and better to be found" (TME 24) also becomes its hidden necessity.

It seems then that the "fate" of modern technology is to tend towards the invention and application of technologies that pose a threat to the existence of human beings and to their existence as agents of responsibility. Jonas attempts to make a contribution precisely to a solution of this problem. In Part 1 of this article, I tried to show that Jonas's myth could be used as an alternative point of access to his thinking, thus relativizing Jonas's main philosophical attempt to answer this question by means of a foundation of ethics in a metaphysics of the organism. The myth does not restore the God that died in modernity, but stands under the remembrance of this God's judgment, as it were. The myth (as was also Jonas's intention with his - failed - metaphysics) presents us with a new monism, one that transcends the pan-vitalistic and the materialistic ones, as well as the millennial tradition of dualism. It does so by bringing together the conflicting elements of life and death in the notion of mortality. Furthermore, it claims a universal validity for the care due to beings suspended temporarily between life and death. Hence Jonas's definition of responsibility: "Responsibility is the care for another being, that is recognized as obligation and that in cases of the threat of the vulnerability of that being becomes 'concern' " (PV 391). ${ }^{3}$ Thus every human action, the totality of the human I can, is informed by the mood of the myth (in other words, a reinterpretation of Heidegger's Sorge) and is (potentially) directed to objects of concern by fear. 
But Jonas is very clear about the fact that he is not interested merely in reconceiving the justification and nature of ethics for modernity, but seeks the opening of his ideas to a "praxis of the principle of responsibility" (as the subtitle of Technik, Medizin und Ethik declares), even to the point of leading to an ethical "casuistic" (cf. PV 10 with TME 9). What are the salient characteristics of this ethics — of practical responsibility?

In order to address this question, the path should be traced forward from the myth. I proceed by taking as obtained what I attempted to argue in Part 1 of this article, namely the continuity between Jonas's work, read from the perspective of the myth, and its original philosophical intention (despite the big differences implied between the non-foundationalist myth and a foundationalist metaphysics). My programme is to (1) explain the status of the myth as ethical intervention $(\$ 2),(2)$ examine the relation between the myth and Jonas's two notions of fear (§3), (3) examine the ethics of responsibility in its two aspects (that is, as a principle of ethics and as practical ethics, respectively) (§4), and (4) analyze important interpretational consequences of the above for a reading of Jonas's work on responsibility $(\S 4-\S 5)$. Of this programme, $\S \S 3$ to 5 could be read independently from the arguments of Part 1 of this article.

\section{On the Status of Jonas's Myth as Ethical Intervention}

To start with, the particularity of the Jonasian myth should be considered: what, if indeed anything, distinguishes it from any other tale? To be sure, our description of the myth as an aesthetic event implies that it evokes what in principle could be evoked by other means. Making a strict claim to exclusivity is thus not implied in the myth; it should be clear that many other narratives could claim to take the position of an evocation of the all-encompassing conviction of the principle of responsibility; that is, the principle of ethicity as such, in the modern technological world. It seems that a valid myth can be recognized by some traits about which Jonas speaks.

Jonas writes the following concerning the ethical, practical nature of a discourse on ethics:

Still, in the practical philosophy, in ethics, where the matter is the good and its opposite in human affairs, something is added, that makes of the relation the theme of the theory and its expression a quite particular relation: the expression becomes instrumental to the realization of that which the theory has demonstrated to be the good or what has to be obtained; it is the beginning of action itself, and therefore no longer, as is otherwise the case with the presentation of knowledge, only service to theory, but already service to matter expounded in the theory. ( $\mathrm{WpE} 27$, my italics).

However, this instrumentality is one that should be clearly distinguished from the instrumentality of the technical order: "For the sake of human autonomy, the dignity that requires that we possess ourselves and that we don't let ourselves be possessed by our machines, we have to bring the technological race 
under non-technological control" (TME 52, my italics). This means that the instrumentality of ethical discourse is of a second order, in that it could guide or steer instrumental, technical events. In this sense it is extra-technological, whilst being instrumental.

But if this argument appears to make a quite simple point, consider what the following statement implies for the freedom of ethical discourse: "The road through dualism here briefly indicated marks the irreversible time-order of the two positions, and dualism itself represents so far the most momentous phase in the history of thought, whose achievement, however overtaken, can never be undone. The discovery of the separate spheres of spirit and matter, which split primeval monism asunder, created forever a new theoretical situation" (PL 16). If dualism, then, is "irreversible," if it "can never be undone" and creates a new theoretical situation that remains "forever new," then this implies a certain captivity of the order of ideas: Jonas himself, in the formulation of his second order instrumental discourse on ethics is not only (attempting to) control the technical milieu, but is being controlled or at least pulled along by the consequences of a spiritual event, namely more than two thousand years of dualism. And even the new monism Jonas pleads for "cannot undo the polarity" (PL 17).

Thus, from these remarks, we can deduce that for any narrative to claim to evoke the all-encompassing conviction of the principle of responsibility, (1) it has to take as a point of departure the existing state of the human spirit and work from there to create something "new" that is, however, under the influence of what is old. Furthermore, (2) at the same time, it should be able to elicit reflection to become instrumental to realizing the mentioned responsibility; that is, steering the technological order, without becoming simply incorporated into the technical, instrumental sphere.

The hazard of proposing such a myth is that its author has no choice but to place himself or herself in the position of the most advanced point of the unfolding potential of spirit, and by implication of God, in the history of humanity. ${ }^{4}$ This is, of course, an unfolding, not as the creator of a new perspective, but as the formulator of, or as a testimony to, what was latently or implicitly there, probably since the beginning of the world (this reading would be true to the spirit of Jonas's cosmogonic supposition [kosmogonische Vermutung PUV ch 10]). One should, however, hasten to add that for Jonas, this history of human spiritual unfolding is no "success story" such as he finds in Aristotle, the Stoics, Spinoza, Leibniz, Hegel, Whitehead, or Teilhard (PUV 244). His universal history is one that is written under the pressing realization of the risky exploit (Wagnis) which the self-renouncing God undertook — risky to the point of history's being capable of producing events such as the horrors of Auschwitz (PUV 244). Therefore, the

(for us the only known) final, youngest, locally infinitesimal appearance of the spirit in it - in us - is rather to be compared with a lost flickering in the most general night; and if the spirit was the goal of this gigantic event, one is, in the face of the 
quantitative disproportion to what was to be obtained (as far as is known to us), rather tempted to speak of a big expenditure that was miserably wasted or, perhaps kinder, also of a stroke of luck in the coincidence of circumstances, of a play of cosmic chance - rather of that sort of thing than of the majestic course of reason through the world. The latter is simply out of question. (PUV 242-243)

If this is what Jonas believes concerning the appearance of spirit in general on the scene of cosmic history, then so much greater the coincidence that cosmic history allowed for the formulation of his myth in him. The realization of an all-encompassing conviction, expressed in the Jonasian myth, may be only a "small flickering" in the immense expanse of cosmic time and space, but it is nonetheless not an anomaly to be reduced to the rule of "general night" - it is the light in which all the obscurity of the world gets its most decisive meaning. Bringing to light, allowing to shine the small light that makes ethical judgment — responsibility — possible in the modern technological world, this seems then to be the first response to the evocation of the possibility of responsibility by the myth: to write the myth as response to the possibility of its validity.

\section{Myth(s) and Fear(s) in the Philosophy of Responsibility}

But if we accept that this interpretation of the consequences of Jonas's myth is correct, it is nonetheless difficult to see how those consequences fit in with the presentation of the origin of Jonas's philosophy as he accounts his personal thinking experience. At least at first glance, the two approaches to ethics seem to be contradictory: the myth as evocation of an all-encompassing context for responsibility and written as response to the possible validity of the myth; Jonas's accounts of his development as philosopher as response to and motivated by fear. Let us first consider the details of the notion that Jonas's personal experience is motivated by fear.

Consider first of all, a number of references in the introduction to the Philosophical Essays of 1974. During the war, for Jonas, the "apocalyptic state of things, the threatening collapse of a world, the climatic crisis of civilization, the proximity of death, the stark nakedness to which all the issues of life were stripped, all these were ground enough to take a new look at the very foundations of our being and to review the principles by which we guide our thinking on them" (PE ii); in other words, here it is not the flickering of responsibility that sheds light on the darkness of war. Instead, the necessity of light is derived from the obscurity of night. The dominant position of fear continued after the war: "For a while I had no illusions about the power of reason in the governance of human affairs, I set great store, with old Hobbes, in the wholesome power of naked fear; ... one may still give the comforting odds to fear of the vividly imminent extreme" (PE xv, my italics). But then came a turn that once again left fear intact: "What recalled me from theoretical detachment to public responsibility and set a new task to my philosophizing ... was the growing realization of the inherent dangers of technology as such" (PE Xvi). Hence the 
justification of his project of philosophical ethics: "Thus it has come about that since the late sixties I find myself — by a transition from 'theoretical' to 'practical' reason enforced by the very pressure of events and even more of the possibilities colossally looming on the horizon - engaged in questions of ethical theory and finally in a quest for the foundations of an ethics adequate to the matters on which we now or soon have to decide" (PE xvi, my italics). Hence also the initial idea to name the collection of essays - which cover work from all three phases of his oeuvre - "Man in Crisis" (PE xviii).

In Wissenschaft als persönliches Erlebnis, Jonas's decision to consecrate his research to ethics is justified, and not merely as a logical consequence of the philosophy of life: "[I]t is something different, if one arrives at ethics from a systematic view or forced by the shock of reality. By 'shock' one thinks evidently firstly of the nuclear arms technology. Still, what brought me to ethics as remaining life task, was not so much the - after all avoidable - danger of sudden atomic Holocaust, than rather the almost unavoidable apparent cumulative effect of our collective, daily practiced technology, even in its peaceful form" (WpE 28, my italics). ${ }^{5}$ This spirit is clearly reflected in the preface to Das Prinzip Verantwortung: "The promise of modern technology has changed into a threat, or that the latter has linked itself indissolubly with the former, forms the starting thesis of this book" (PV 7, my italics, not in IR). Hence the impatience with which he writes: "[B]oth the limits of life [i.e., the shortness of life left to the author - EW], [and] the urgency of the matter" (PV 11, not in IR) make him opt to write in German rather than in English, in order to win some time.

From all the cited biographical accounts, it is evident that Jonas was motivated in the development of his philosophy by fear and not, for instance, by the appeal that his myth would make on him. It should be clear that this "shock" and "fear" are not the heuristics of fear that Jonas presents to his readers in the preface of Das Prinzip Verantwortung as a "compass" to orient them in a world of unheard-of ethical problems created by the dawn of modern technology (PV 7-8). The fear of Jonas's biography imposed itself on him; the heuristic representation of a possible threatening future scenario, as well as the fearful response to it, both have to be obtained or produced actively and reflectively (PV 65). The first fear is pathological, the other is a fear of a "spiritual nature," namely "letting yourself be affected" (cf. PV 65/IR 28) 6 . In other words, the shock and fear that we learn about from Jonas's biographical sketches cannot be considered the result of a heuristically oriented futurology, but should be regarded as an initial impression that initiates both the futurology and the Prinzipienlehre.

The heuristics of fear is a creative preparation of suitable ethical conduct on the basis of the best available knowledge (PV 62) and comes only after a first fear of which the human being is not the master: "[T] hus the necessary willingness [i.e., the heuristics of fear - EW] can get something very involuntary [i.e., the first fear - EW] as help from the things themselves: shock of real and 
repeated catastrophes of smaller dimensions, that give us the proper fright for the big catastrophe, with which the technological excess threatens our future" (WpE 44-45). The heuristics of fear is part of the project of justifying the principles of ethics and of developing from there an applied ethics. Its execution is carried out in obedience to the obligation (Pflicht) that is already based on the established principle of responsibility, but all of this seems to be done as a response to an initial fear that is neither necessarily informed by knowledge (as the heuristic fear is), nor necessarily informed by the justified principle of ethics.

Having considered the place and nature of fear in Jonas's personal development, we are now in a position to clarify the question, formulated at the beginning of this section, of the relation between the motivation by the myth (as justification of ethicity as such) and the motivation by an ever-growing fear (in the heart of the individual person; in this case, Hans Jonas) to react to the frightening situation of the world (in Jonas's case this reaction entails the development of a philosophy of ethics). To start with, we should distinguish two divergent forms of inherent logic according to which the two motivations work: (1) whereas (in my reading thereof) the myth provides a narrative evocation of or testimony to the originary but non-foundational source of ethics to which Jonas as individual responds in his work, amongst others by his heuristics of fear, (2) his autobiographical portraits clearly put anguish in the centre and motivate action from an apprehended catastrophe. Seen in this way, both motivations interpret reality in its confrontation with a non-real vision: either the myth or the projected catastrophes. However, they remain divergent in three important ways:

1. The logical point of departure is different: instead of reflecting on the conditions for the possibility of proven acts of responsibility (a refusal to repeat Auschwitz; support for caring parenthood) as is done by the myth, shocking possibilities are taken to be the primary phenomena that have to be explained; instead of ethical human action, terrible events have to be understood. Furthermore, the perspective of the myth is directed primarily to the past and present, whereas the perspective of the projected catastrophes is directed primarily to the unknown future.

2. The content of this fear, as described by Jonas, differs from the content of the myth: in the myth, it is true, God takes a risk regarding what human beings may do to the divine image, but even Auschwitz seems not to have made an end to this dispensation; ${ }^{7}$ the events that provoked Jonas's fear, however, threatened to be "even worse," in the sense that they put this dispensation at stake - they opened up the possibility of the destruction of humankind itself. One could also say that whereas, in the myth, the self-renunciating God seems to remain in the centre of consideration, in the face of fear, humanity appears to be the main concern. 
3. Whereas the myth narrates a general all-encompassing mood, the fear, though also an encompassing mood, is directed more specifically to things about which it fears for the future. The myth throws an equally valid light on all phenomena; fear cannot apply to all phenomena equally, since it is aimed at particular things or events, even though some of these could be very extensive.

With this typology in mind, we might consider the possibility that the fear of projected catastrophes might also be put into narrative in a myth with a comparable aesthetic structure. It would thus also be a myth in the light of which the entire reality appears, in particular all human action, but, since it is directed at the future, it places the present planning of action in a particular light. This light is that of catastrophes of eschatological proportions; if it were to be narrated, it would be a myth of human self-destruction. One could also state that underlying the autobiographical episodes in which Jonas describes his fear there is an implicit myth of human self-destruction. This would likewise be a "glass through which we darkly see" (PL 261), a "likely imagination" (PL 275) or a "supposition" (Vermutung) (following the description of myth and its interpretation given in Part 1 of this article). If this is the case, what would be the relation between the myth of the self-renunciating God and the myth of eschatological human self-destruction?

Despite the tension between the two, I propose that the latter myth be seen as an extension of the first. The myth of eschatological self-destruction is the sequel to and already announced at the end of the myth of the self-renunciating God. The two imply one another as question and response. Whereas the first contemplates ethicity from the point of view of cosmogony, the second would narrate the fate of humanity as the inheritor of God's risk of self-renunciation. The fear of the myth of human self-destruction is only apparently or strategically anthropocentric, in the same way that the role of humanity is special in the entire framework of responsibility (as described in Das Prinzip Verantwortung); in essence, however, what is feared in immanent catastrophes is not the loss of effective self-preservation of humanity, but rather the destruction of the image of God as projected by the doings of humankind. This would not mean that humanity is only instrumental to the salvation of God; instead, it means that the preservation of humanity is not merely an issue of efficiency - it is an issue of ethics.

If this rendering of Jonas's first fear is accepted, it would follow that this fear is to be considered an effect of the shadow of the withdrawn God's "balance sheet" or judgment $\left(\right.$ Bilanz — PUV 197) ${ }^{8}$ as it falls on the person of Hans Jonas. As such it is claimed for the fear that precedes the heuristics of fear and that sets Jonas's ethical response in motion that it is not merely a numbing, pathological fear; instead, it is presented as an exegesis of divine judgment. (How one has to distinguish in practice between pathological fear and fear as exegesis of divine judgment is not at all clear.) This fear as exegesis is thus the 
all-important event by which human beings are affected by the ethical. It is the very call to responsibility: "To grant that appeal a hearing is precisely what the moral law commands: this law is nothing but the general enjoinder of the call of all action-dependent 'goods' and of their situation-determined right to just my action" (PV 162/IR 85, cf. also PUV 131). Being able to fear is, in the light of the myth, a positive human capability, a sensitivity that constitutes that special kind of hearing of which Jonas speaks (and to which I have referred in Part 1 of the article, $\S 4.1)$ :

Why may we not, like animals, do everything that we are capable of? Including self-destruction? Since being says so? But as is well known, as all modern Logic and Philosophy teach us, it doesn't say anything at all on this, no "ought" follows from any "is." Now, all depends on the "is." One has to see it and one has to hear it. What we see, embraces the evidence of life and of the spirit [Geist] — witnesses against the doctrine of a nature that would be foreign to value and to ends. What we hear, is the call of the good that is seen, its inherent claim to existence. Our capability to see and hear makes us to beings that are called upon [Angerufenen] by its commandment of recognition and thus to subjects of an obligation towards it. (PUV 247)

Fear, in this sense, is the being-affected-by, the taking-form or first incarnation of the appeal that the valuable being of living things makes on the subject. Hearing the appeal of what is valuable in itself is the first response to it; but this response is possible as obedience, as giving heed to it, only in the light of the myth. And it is only from this perspective that the original fear is capable of leading to a heuristics of fear in which fear is not pathological but a "selfless fear."

But this fear does not only focus the myth on me as the person who is to answer the call of the needy. As registration of the judgment of God, it is a direction of the ethical character of the myth to a particular theme. Fear is fear for something that is in need of care or protection.

Through this double mythological rereading we have reformulated the justification of the principle of responsibility in a modern technological civilization. This corresponds to the first element of the initial three-fold step towards the implementation of the principle of ethicity: this step consists of "[1] the wake up call of the foundation itself and then [2] the creation of awareness and education of feeling, that [3] could proceed from the futurology that is practiced under the influence of it" (PUV 143, cf. also PV 390-393). It is to the particulars of this ethics of responsibility that I now want to turn my attention.

\section{Two Notions of the Principle of Responsibility}

If fear is the fear for what is in need of care (as I concluded in the preceding paragraph), and if the aim of the reflection on it was to decipher the care inscribed in the very fibre of our human being, then we are just one step away from the practice of responsibility, since "[o]nly for the changeable and 
perishable can one be responsible, for what is threatened by corruption, for the mortal in its mortality" (PV 226/IR 125-126). Being responsible for such threatened beings, we shall see, finds expression in practices such as "the heuristics of fear" and "the pre-eminence of the disaster prophecy" (Vorrang der Unheilsprophezeiung). However, it would be a frightening error to pass too quickly from the justification of responsibility to its practice. The reader will notice that thus far the discussion has covered only the justification of responsibility and some of its consequences. A close reading will show that in Jonas there are in fact two philosophies of responsibility. This claim needs to be explained and argued before the two philosophies of responsibility can be delimited and the question concerning the relation between them can be posed. Failure to do so would inevitably jeopardize the entire philosophico-ethical enterprise.

\subsection{The Distinction: Terminological Orientation}

Although Jonas himself does not make the distinction between his two philosophies of responsibility, we can deduce it quite efficiently by looking at the way the term "Prinzip" is used in the book by Jonas that includes this word in its title. At the end of chapter 2.III (PV 80-83), Jonas declares that he has found the "principle" (Prinzip) (PV 81) on the basis of which the "instruction" (Vorschrift) of the decision or verdict (Entscheidung) for "disaster prognosis" (Unheilsprognose) against "benefit prognosis" (Heilsprognose) can be imposed on human action as a moral guide (the instruction would then be the pragmatic expression, pragmatischer Ausdruck, of the principle - PV 81). This principle is formulated as "an unconditional duty for mankind to exist" (PV 80/IR 37), which expresses in the indicative the content of the obligation that is elsewhere formulated by the categorical imperative: "Act so that the effects of your action are compatible with the permanence of genuine human life on earth" (and the three equivalents thereof, PV 36/IR 11, translation modified) (PV 36). Right after having announced that he has found this "principle," he then reformulates it in the following words: "The foundational rule of ethics, from which the instruction [ = of the preference for the disaster prognosis — EW] receives its validity, is as follows: the existence or essence of the entire human race may never be made a stake in the betting [or risk taking] of action" (PV 81, my italics). From the context, it is clear that this "foundational rule of ethics" (ethische Grundsatz) is the "principle" from which the instruction regarding the priority of the disaster prognosis derives its validity; in other words, "principle" is here synonymous with "foundational rule of ethics." (By stating this, Jonas delivers on his promise that the instruction of the priority of the disaster prognosis could "be taken as occasion for a new foundational rule" [PV 70].) However, one page further, Jonas concludes the section by explaining that in everything that preceded - that is, including his declaration of the discovered principle as foundational rule - it had been tacitly presupposed that there is indeed something like human 
responsibility (PV 82) and that the "principle of responsibility as such - the starting point of ethics — has not yet been demonstrated" (PV 83/IR 38, my italics). ${ }^{10}$ In other words, even though the principle-as-foundational-rule has been discovered, the principle-as-beginning-of-ethics still has to be found. From this it should be concluded that the principle-as-foundational-rule that is the foundation for the instruction (Vorschrift) is in turn founded on the principle-as-beginning-of-ethics; that is, the principle of responsibility as ethicity as such.

We thus have to do with a polysemy of the notion "principle" that in turn spontaneously leads to a double meaning of the title "Das Prinzip Verantwortung," in respect of what the principle of responsibility is. It should be noted that this double meaning of the principle of responsibility does not correspond with the double aspect of a theory of responsibility that Jonas indicates, namely its objective justification and subjective appropriation (cf. PV 163). This non-correspondence is due to the fact that the two notions of principle that I have just indicated both fit into the window of the objective justification.

This haziness could be clarified in the following manner. The ultimate principle of ethicity (which, if it is real as a principle at all, is true and valid independent of human recognition - according to Jonas's understanding of it) that carries the name "responsibility" manifests its effect in the fact that tacit recognition is given thereof in the fear that people have for the lives of others (cf. the cases of refusal of a repetition of Auschwitz and of neglect in parenthood, as used previously) and is ex post facto justified by a myth (or by metaphysics, if one follows the orthodox reading of Jonas, especially of PV chs 3 and 4), by means of which an attempt is made to say the unsayable. The myth throws a light on the entire human existence and by so doing makes possible an exegesis of this fear. This in turn justifies ethical conduct in general. This justification by means of the myth is already a first gesture of response to the obligation inscribed in the myth, but the emotion of fear is already an appropriation of that ultimate principle of responsibility. Since this appropriation aims at care for the other (as that which is valuable in itself), attention should be given to care for the other according to justifiable guidelines. The first step toward the identification of such guidelines is given by the attempt to identify a foundational rule or foundational rules that would faithfully translate the concern of the myth into the imperative form from which the appropriate guidelines or instructions (Vorschriften) could be derived. Amongst the series of possible foundational rules, Jonas is first and foremost concerned with that of responsibility; namely, that in the current era of history the continued existence of humanity should be an all-encompassing duty (for this, see especially PV chs 1 and 2).

Having identified the two principles of responsibility, we are now in a position to distinguish them systematically. From this description, the relation between them will also become clearer. 


\subsection{Main Characteristics of the Principle of Ethicity and the Principle as Foundational Rule}

It should be stated that the ambiguity concerning the principle of responsibility is of Jonas's making (as some of the passages cited below will show). The systematic distinction between the two forms of the principle of responsibility that follow is not so much based on Jonas's statements of self-interpretation as on what he actually does. I therefore do not claim to be able to accommodate every single statement of Jonas on responsibility in my "two responsibilities" interpretation, but I do claim that I can do so for the vast majority of them and, more importantly, I claim that this interpretation is true to the spirit of Jonas's work and can make a significant contribution to its clarification. Demonstrating this claim is the purpose of what follows.

A helpful typography of Jonas's presentation of responsibility has already been presented by Micha Werner, ${ }^{11}$ and it would be superfluous to repeat it here. What is, however, of great interest to us here is that Werner is mistaken in one essential point. Objecting to M. Kettner's claim that Jonas places responsibility at the center of ethics, from whence other ethical terminology is to derive their meaning, he also states categorically (unlike R.-P. Koschut) that an " 'identification' of the ethical with the 'principle of responsibility' 'is expressly not intended by Jonas. " "12 As alternative to these errors, Werner insists that Jonas does not attempt to present a general ethics, but only an "ethics of completion" (Ergänzungsethik).

My problem with Werner's polemics resides in the fact that he opposes two readings of Jonas's philosophy of responsibility as if only one is valid. I would claim that both of these apparently opposing "alternatives" are valid at the same time, but are applicable to different levels of Jonas's philosophy..$^{13}$ There could be no question about Jonas's identification of the ethical and the principle of responsibility if one accepts that what Jonas calls the "principle of responsibility as such - the starting point of ethics" (PV 83/IR 38) finds its philosophical expression in his arguments against nihilism. ${ }^{14}$ Although he recognizes that his metaphysical response to nihilistic scepticism is perhaps without any hope of success (PV 102), Jonas still promises to present it as the basis for the answer to Leibniz's question, "[W]hy is there something rather than nothing?," which he reinterprets as enquiring not about the origin of things, but about the reason why things that exist are worthy to be (cf. PV 99). It is his arguments in favour of the objectivity of value that aim at affirming also the objective validity of its obligatory nature (cf. PV 102). In other words, the arguments by which Jonas attempts to prove the valid transition from "is" to "ought" (especially in PV chs 3 and 4) is a defence of "the beginning of ethics," of the "principle of responsibility" as such, and thus of the ethical as such. ${ }^{15}$

However, it should be conceded that it is not clear why ethicity as such should bear the name "responsibility." One gets the impression that the structure of Das Prinzip Verantwortung by which the content of responsibility is presented before its ultimate justification prejudices the reader to accept it; 
Jonas does not argue for it. If the importance of the philosophy of the organism for the principle of ethicity as such is taken into account and if, furthermore, one does not forget the Heideggerian inspiration thereof (cf. PL 86, PV 144, PUV 14, 25-28), then at least a prima facie case could be made for calling the principle of ethicity as such the "principle of care."

What, then, does responsibility as the principle of ethicity as such consist of? For all intents and purposes, it is an a-historical ${ }^{16}$ principle. Since it is the principle of ethicity as such, it is the timeless (as Jonas presents it: metaphysical) countering of value relativism or nihilism. The manner in which Jonas argues for this principle (his natural teleology) makes it clear that it cannot be considered a principle of an ethics of the technological civilization exclusively, but should be seen as the principle of all true ethics of all ages. On the other hand, it hardly needs justification that the principle of responsibility as a foundational rule is a historically and culturally contingent element of ethics, and specifically pertinent for the era of advanced technology. The small theory of modernization in chapter 1 of Das Prinzip Verantwortung provides the required background thereto. The technical formation of modernity calls for a principle of responsibility that is the ethics of a historically unknown kind of human being and a specific kind of agent for a task that is also created by the modern technical condition that has brought forth this new human being by changing the nature of human action. In this era, the fact of the far-off and future consequences of actions and the disproportionate relation between (extensive) knowhow and (relatively limited) knowledge concerning consequences should supplement former forms of ethics. Because of this newness, this fact needs to be central in the reflection of ethics now. Even if it were to be accepted that such an ethics of responsibility did not say much to former generations, Jonas would affirm that they were ethically, caringly responsive to others by other means, but on the basis of the same responsibility-as-ethicity.

Because of the span of the metaphysical (and mutatis mutandis also the mythical) justification of responsibility as ethicity as such — to show how the subject is only the tip of the iceberg (PV 140 ${ }^{17}$ ) of organic life; in other words, to show that the human subject is dependent on a much larger psyche - it should be clear that the "yes" that is part of the very fibre of life should be the principle of all (valid) forms of ethics. It provides a much broader basis or justification than just what is needed for the historically contingent ethics of responsibility for which Jonas pleads. Thus the ethicity of the "yes" of life - the beginning of ethics - serves to justify many other imperatives and other ethical discourses than just the categorical imperative for "an unconditional duty for mankind to exist" (PV 80/IR 37). Someone might object that this "yes" of life is no ethics at all, and that what I, with Jonas, called the beginning of ethics or the principle of responsibility as such is a blind force that is at work within life in very much the same way as the power of one's digestive system is. But such an objection would fail to appreciate the importance that the reinscription of ethics "in the breadth of being": the reader who thus reduces responsibility 
to acts of the conscious subject has thereby ignored the monism that Jonas has pleaded for so passionately. Such a reader runs the risk of succumbing to Jonas's criticism of contemporary Gnosticism. In fact, one could schematically summarize the lesson of chapter 3 of Das Prinzip Verantwortung as an argument that it is only because I have a digestive system (as emblematic form of my participation in the broader phenomenon of life) that functions as it does (life-affirmingly) that my hammer (as metonymy for the actions of which I as agent am capable) can have an aim at all and that on this basis the use of the hammer is submitted to ethical judgment. If responsibility-as-ethicity is conceived of as an iceberg, then the life of the responsibly acting subject could be compared to another iceberg standing with its tip on the former, and where the huge volume of the second iceberg stands for the actions of the subject and their historical consequences. The point at which these two icebergs touch is actually one point: the thinking, ethical subject. In as far as this subject is to act responsibly, its action is built on the small point constituted by the realization of the categorical imperative for the obligation to safeguard human life.

The inscription of responsibility in ethicity as presented through Jonas's natural teleology confronts us with different notions of individuality and collectivity in responsibility-as-ethicity and in the responsibility-as-foundational-rule. In the light of the previous paragraph, we might retort that the psyche originally does not belong to any individual subject and that such an entity could not constitute an ethical agent. However, the relevant passages ${ }^{18}$ should be read carefully. Jonas explicitly distinguishes psyche, which covers the aspect of "striving" (Streben) and which belongs to "all material formations that have a certain form of order" (aller Stoffverbände gewisser Ordnungsformen - PV 141, and 142) from subjectivity (as "selfhood," Selbstheit - PV 142). Psyche is thus characteristic of all organic life, whereas subjectivity as mutation of psyche is to be found only in the higher organisms and is, as such, a "surface phenomenon of nature" (Oberfächenerscheinung der Natur - PV 142). Although Jonas is not eager to be drawn into speculation on it, he concedes the possibility of an "unconscious total subject" (bewußtloses Gesamtsubjekt) of nature, but states that he would "sooner believe in subjectivity without subject, that is, in a scattering of germinal appetitive inwardness through myriads of individual particles, than in its initial unity in a metaphysical, all-embracing subject... . Distinct 'units' of ordered groupings (patterns) of the manifold, whether organic or inorganic, would then already be an advanced result, a crystallization as it were, of that scattered 'aiming,' and it would carry with it difference from the surroundings, or individuation" (PV 142/IR 73, my italics). To summarize: every human being is, already at the pre-subjective level, gifted with an individualised participation in the general fact of "purposefulness" (Zielstrebigkeit) (as seen in the working of the digestive system) that is dispersed throughout all of nature. ${ }^{19}$ Even if one were to decide (unlike Jonas) that there is a collective natural psyche, Jonas would plead for it to be divided into all the different individuals that participate in it (cf. PV 142). 
Having established this, how should the notions of collectivity and individuality then be connected to the two respective forms of responsibility (as ethicity and as foundational rule)? The agent of the principle of responsibility as ethicity, or rather, the agent that is subjected to the principle of ethicity is each individual human being in as far as he or she as psyche participates in organic life and its teleological structure; every human being is structured in such a manner as to be subjected to the affirmation of life. However, in human beings, this psyche undergoes a particular mutation, or specialization, in the form of Selbstheit, subjectivity, that is capable of acting out interpretations of this primordial imperative. ${ }^{20}$ One form of heeding the primordial affirmation of life is the ethics of responsibility, built on the responsibility-as-foundational rule, the bearer of which is human collectivities (and individuals in cases where such an individual responsibility could be derived from the collective one). Hence the paradox of the two principles of responsibility: being rooted in the (possibly) collective teleology, every individual organism possesses ethicity as the principle of responsibility individually, but the originally individual human subject is, first and foremost, collectively responsible. Hence also the paradox of the intuitionist part of Jonas's ethics of responsibility: human beings in the era of modern technology are subject to a collective responsibility, but they appropriate that obligation individually through a feeling of responsibility.

We could test the claim that ethicity as such applies to the individual before the collective, by referring to the fact that Jonas apparently makes this claim of the responsibility-as- foundational rule. Consider the interview "Possibilities and Limits of Technical Culture" (Möglichkeiten und Grenzen der technischen Kultur), in which Jonas said about the "ought-question" (Sollensfrage):

I have made an appropriate attempt with the unhelpful means that contemporary philosophy (that has exactly renounced metaphysics) offers, to lay a speculative foundation for claiming that humanity and hence also every member of humanity, thus every single individual, actually has a transcendent or metaphysical obligation to assuring that there will be also future human beings, embodiments of this human genus, on earth and, to be precise, under living conditions that that would still allow for the realization of the idea of the human. (TME 292)

To this objection, I would suggest a particular reading of this citation: every individual in effect has the metaphysical obligation, yes, but when this obligation takes - amongst many others - the form of responsibility for the continued existence of humanity, then it applies in practice first to collectives rather than to individuals. This interpretation of mine could be supported by reference to Das Prinzip Verantwortung where Jonas says explicitly of the new imperative (formulated on the previous page): "It is also evident that the new imperative addresses itself to public policy rather than private conduct, which is not in the causal dimension to which that imperative applies" (PV 37/IR 12). He puts it even more strongly where he asks who the responsible human being 
is and answers: "Not you or I: it is the aggregate, not the individual doer or deed that matters here" (PV 32/IR 9). The pages preceding the citation from the interview under discussion can also be used to support my argument, where Jonas plainly refers to responsibility as the "responsibility of authorities of action [Handlungsinstanzen] that are not individual persons any longer, but our politico-social unit" (TME 274). That is why the ethical dilemmas of the technological civilization are matters for "collective policy" (kollektive Politik - TME 275). He goes on to explain the question of responsibility in this particular era as follows: "What can 'we' do about it; 'we', namely this entire, big super-subject that acts as a whole, today's technical-civilized humanity what can we do bout it [... etc.]?" (TME 275) — the agent of responsibility is "we" in this sense. When he asks the question concerning the identity and power of the subject of responsibility, Jonas starts by first acknowledging the experience of the anonymity of power in the contemporary technical world — what people experience as fate (cf. TME 283) - before he reminds us that every one of us is a co-agent (Mithandelnder) (TME 284). That is why the uncompleted task of seizing the power that is needed for truly responsible action is found in institutions (that is, mechanisms of collective action) that are still to be formed (cf. TME 284).

\section{Conclusion}

Having advanced the distinguishing characteristics of this double theory of responsibility, in conclusion, the implications of this theory should be outlined and reflected on.

\subsection{Implications of the Twofold Theory of Responsibility}

If Jonas argues that responsibility as ethicity impregnates the pre-subjective life of the human organism, then it means that he does not make ethicity dependent on reason. Ignorance and competence are categories that simply do not apply to this form of responsibility. However, the kind of responsibility required for the age of advanced technological complexity is one that depends intimately on the best knowledge available. In fact, knowledge becomes a key part of the duty of responsibility and it strives at doing the impossible, namely to bring our understanding of the situation up to the level required by the nature of our action (cf. PV 28). The ethics of responsibility are, after all, characterized and called for by the disparity between what we are capable of doing and our knowledge of the consequence of what we are capable of doing. The importance of advanced, expert knowledge finds its expression in the two instructions of the heuristics of fear (the component of futurology) and of the primacy of the disaster prognosis (since the latter can be determined only on the basis of expert knowledge). ${ }^{21}$ It is of this responsibility then that Jonas says that it is "a function of power and knowledge" (PV 222/IR 123).

If this is the case, then it seems inevitable to conclude that those who have more knowledge and more power to effect changes on the basis of that 
knowledge are to be considered to be under a heavier load of obligation to responsibility (but not necessarily to other forms of obligation). I doubt that the affirmation of life - in other words, the principle of ethnicity — could be quantified in a similar fashion. It would probably be safer just to say that it imposes a moral obligation on all people. This means that the principle of responsibility as ethicity as such is always equally and evenly valid; however, not only is responsibility as a foundational rule a historically contingent ethics, called for by responsibility as ethicity within this particular era of socio-cultural reality, but it results in a heuristics of fear that is constantly informed and re-informed by the progression of knowledge of our actual world. In other words, whereas responsibility as ethicity has a non-contextual effectiveness, responsibility as foundational rule calls for a hermeneutics of perpetual revision of the situation. ${ }^{22}$

Who then is the beneficiary of responsibility in each case? In the case of the principle of responsibility as such, it seems to be life. This follows from the conviction that teleology as such is good in itself. On the basis of this notion of ethicity, it is possible for Jonas to conceive of the possibility of an ethics directed at non-human living beings too (cf. PV 189). Most of his attention, though, is directed at responsibility as a foundational rule that applies to humans. To be more precise, humans as recipients of this responsibility are characterized by two essential characteristics: first, by the fact that they can be responsible; second, by the image of humanity. If it is true that being the bearer of responsibility is a defining characteristic of the human being equal to that of the fact of having speech (cf. PV 185), then this holds not only for the agent of responsibility, but also for the (future) beneficiaries of that responsibility. In fact, the basic obligation (Grundpflicht) of current agents of responsibility, from which all other obligations to future generations are derived, is the obligation to safeguard their capacity to have obligations ascribed to them (cf. PV 89). ${ }^{23}$ That is why the development of "behavioural control" (Verhaltenskontrolle) is an ethical dilemma: it contains the possibility of threatening capacitating or "enabling care" (freigebende Fürsorge) by an incapacitating or "pre-empting care" (entmündigende Fürsorge) (PV 51/IR 20). It is the capacity to be an agent of responsibility (what Jonas calls the "Ebenbild," "the image that is not to be violated"24) for which we should have reverence (PV 392-393/ absent from IR). Whereas the conditions under which the other as potential agent of responsibility has become a stake for ethics are historically contingent, it seems to be Jonas's intention to assert that this image (Ebenbild) is to be maintained and safeguarded forever. It is, however, a temporal and fragile image, since it is only as old as humanity and can be changed or destroyed under current technological circumstances. ${ }^{25}$ It is precisely the protection of this image that is not to be violated (and not only the continued existence of the biological species, Homo sapiens) that Jonas has in mind in the formulation of his categorical imperative: "Act so that the effects of your action are compatible with the permanence of genuine human life on earth" (PV 36/IR 11, translation modified, my italics). 
The deepest principle of an ethics of the future is an ontological idea that is capable of bringing forth an obligation (cf. PV 92). This ontological idea is that humanity has to exist for humanity to exist well (cf. PV 91). This notion implies, in other words, what we already know from Jonas: the affirmation of (human) life that is inscribed in the very fibre of the life of organisms is the principle of ethicity as such (even though Jonas states that this principle, being a part of metaphysics, does not form part of ethics as philosophical discourse, PV 92). It is only on the basis of such an affirmation of individual or collective life that a foundational rule of responsibility could be formulated which demands "an unconditional duty for mankind to exist" (PV 80/IR 37), without this being equal to the "conditional duty of each and every human being to exist" (PV 80/IR 37, translation modified). We could accept this if, and only if (as Jonas indeed concedes), this responsibility is to be completed by a range of other forms of ethics that are all intended to remain equally true to the affirmation of life, albeit by other means. If this condition is not fulfilled, we would have reason for great concern ${ }^{26}$ when Jonas explains: "Even when in the fateful hour the political leader hazards the whole existence of his tribe, his city, his nation, he yet knows that even should they be destroyed, mankind and a living world on earth will go on. Only in the framework of this overarching supposition is the single hazard, in certain extreme cases, morally defensible" (PV 80). It seems permissible and vital to infer that it is the co-existence and equal legitimacy of other valid forms of ethics (for instance, an ethics of justice) with the ethics of responsibility (that is, with the foundational rule of responsibility, but also on the basis of responsibility as ethicity) that could determine when a case is truly "extreme" (äußerst). Without these other ethics, the individual faces a formidable opponent in a collective-oriented responsibility and in those who consider themselves the elected executors of the ultimate interests of the collective in these extreme cases. This collective is always humanity, not the individuals who constitute it. ${ }^{27}$ It is this particularity of the ethics of responsibility that makes the idea of its application to non-symmetrical relations acceptable, without anybody's being able to consider seriously that non-symmetry is a quality of all ethical relations.

\subsection{Transition between the Two Forms of Responsibility and Their Relation to Other Ethics}

The conclusions above enable us to add two further points of clarification to Jonas's philosophy of responsibility, namely on the question of (1) how the two forms of responsibility relate to one another and (2) how the two forms of responsibility relate to other forms of ethics.

From the preceding discussion, it follows that the point of transition from the first principle of responsibility as ethicity to responsibility as the ethics for the technological era is the specific formulation of the new categorical imperative: to the side of ethicity it expresses the value of life, in particular 
the inherent value of humanity, in the form of an imperative that is valid for every individual; to the side of responsibility for our era, it makes an appeal to collective obedience. Emotion accompanies this transition as the subjective appropriation of ethics. In fact, it now becomes clear why it was necessary to distinguish between two forms of fear. On the one hand, the initial fear testifies to the ethicity of the human being and could only be called a "feeling of responsibility" if responsibility is, in this case, equivalent to ethicity as such, since it is a fear without or before the principle of responsibility practised in the heuristics of fear. It would probably be clearer to call it a "feeling of obligation." On the other hand, in response to the initial fear, the categorical imperative of responsibility for the technological era is reflectively identified and then obeyed, amongst other things by a process of information acquisition and futurology by means of which the second fear is generated in order to mobilize people collectively to cope with contemporary ethical challenges.

Furthermore, on the question of the kind of practical strategies called for in responding to these challenges, the articulation of the relation between the two philosophies of responsibility also brings some clarification. According to Werner, the diverging receptions of Jonas's work force us to conclude that Jonas does not give a clear answer as to the kind of action called for in responsibility or, as Werner presents the dilemma, it is not clear to what politicomoral subject Jonas's ethics is primarily addressed. ${ }^{28}$ Werner identifies two types of reading or perhaps two extreme readings of Jonas in this regard, namely the "individualistic-anarchical" and the "authoritarian-elitist" poles. It is, of course, impossible to review all the different readings here. Nevertheless, it is important to indicate the manner in which both of these extremes can lay claim to some form of support from Jonas: the "individualistic-anarchical" reading draws on passages explaining the individual, all-encompassing obligation of responsibility as ethicity itself, whereas the "authoritarian-elitist" reading draws on Jonas's insistence on the collective nature of contemporary responsibility and on the need of knowledge, power, and institutions to obey its call. Again, I propose that the solution to the dilemma is not to be sought in choosing any one of these alternatives, but in correctly situating the two readings in respect of one another, since they both contain a moment of truth. Both interpretations are valid, but both are valid only partially. The second interpretative reading (the "authoritarian-elitist" pole) is clearly supported by my exposition of responsibility as obedience to the foundational rule of responsibility and therefore requires no further comment. But if it is affirmed that the second reading is compelling, how could the first reading (the "individualistic-anarchical" pole), which is clearly in tension with the second, claim any validity? This seems to me to be possible only with reference to ethicity itself. But how is this possible, if ethicity itself is not an ethics but the originary "yes" of life, for life? The "individualistic-anarchical" interpretation could claim validity, perhaps not by claiming that it renders ethicity 
in an unmediated manner, but by arguing that the ethics of responsibility is not exhausted by the foundational rule of responsibility; in other words, by affirming that, in the name of responsibility as ethicity, a number of forms of action may be justified ethically or could lay claim to being responsible (in the sense of being true to responsibility as ethicity), even if not all of them meet the requirements of the collective responsibility as obedience to the foundational rule of responsibility (or even if they contradict or supplement what obedience to responsibility as a foundational rule would dictate). I consider it an important task to reread the commentaries that justify this first tendency of reading Jonas and to enquire if they do not all either slip into the second interpretation (by recognizing implicitly that the knowledge used for the heuristics of fear is actually collective and that hardly any individual action could be effective in the face of the challenges to which responsibility is to give an adequate response) or present an ethics that is an ethics of responsibility in the sense that it draws its resources from ethicity as such but in practice boils down to a form of ethics other than the responsibility-as-foundational rule.

We have seen above that in a number of important test cases (for instance, the statesman putting at stake the survival of his country, without endangering the survival of humanity), intuition suggests not only that responsibility should be considered a fundamental ethical practice (fundamental in the sense of keeping ethical agency possible) but also that the logic according to which responsibility works needs to be disrupted or interrupted by another equally valid ethics (for instance, an ethics of justice). Again, it should be stressed that neither this disrupting ethics nor the responsibility-as-foundational rule can ever be ethicity itself, since nobody can claim to be the unmediated spokesperson for ethicity as such - even though we are all ethically constituted by ethicity as such, all ethics are mediated interpretations of ethicity. These other possible, valid forms of ethics are then not simply ethical relics from ancient times that remain in force in a technological era that has radically changed ethical problems and ethical agency. They are important accompaniments of an ethics of responsibility, without which it seems quite possible that some acts of responsibility can be questioned as to their fidelity to ethicity. It seems then that the question of the relation between responsibility and other forms of ethics is not a secondary matter, but rather one that touches on the very heart of the philosophy of responsibility.

It should thus be considered one of the most important defects of the work of Jonas that this question is not properly addressed. This defect is exacerbated by the fact that it has been pointed out by numerous authors that the very notion of responsibility remains quite narrow, ${ }^{29}$ which is one of the sources of the vagueness with regard to its application. It is quite possible that the difficulty that Jonas has in developing the casuistic of responsibility that he promised (PV 10, $67,68,77$, TME 9) is due to the fact that such a casuistic remains inconceivable when other forms of ethics are not taken into account at the same time. 


\section{Notes}

The following abbreviations are used to refer to the works of Jonas in this essay and the essay that precedes this one: PL: The Phenomenon of Life. Toward a Philosophical Biology (Chicago/London: University of Chicago Press, 1966); PE: Philosophical Essays: From Ancient Creed to Technological Man (Englewood Cliffs, New Jersey: Prentice-Hall, 1974); PV: Das Prinzip Verantwortung. Versuch einer Ethik für die technologische Zivilisation (Frankfurt-am-Main: Suhrkamp, [1979]1984); TME: Technik, Medizin und Ethik. Zur Praxis des Prinzips Verantwortung (Frankfurt-am-Main: Suhrkamp, [1985]1987); WpE: Wissenschaft als persönliches Erlebnis (Göttingen: Vandenhoeck and Ruprecht, 1987) and PUV: Philosophische Untersuchungen und metaphysische Vermutungen (Frankfurt-am-Main/ Leibzig, 1992).

Once again, for the purposes of this study, the books are referred to in the language English or German - in which they first appeared. For Das Prinzip Verantwortung, I used the translation entitled The Imperative of Responsibility. In Search of an Ethics for the Technological Age (Chicago/London: University of Chicago Press, 1984), abbreviated as IR. The page numbers indicated refer first to the page in the German text and then to the page in the English translation; for references without quotations, the page numbers refer to the German text, where that is the original and first publication.

1 See Ernst Wolff, "Responsibility in an Era of Modern Technology and Nihilism, Part 1. A Non-Foundational Rereading of Jonas," in Dialogue 48 (2009): 577-99.

2 Modernity is characterized by dynamism (PV 216) and this in turn is due to the “"Selbstbewegung' der Technik" (PV 404 n. 22). It should be borne in mind that the word "progress" as used in this sentence is used first and foremost as a descriptive, rather than as an evaluative, term (cf. TME 20).

3 My translation (IR) does not appear to contain this passage: "Verantwortung ist die als Pflicht anerkannte Sorge um ein anderes Sein, die bei Bedrohung seiner Verletzlichkeit zur "Besorgnis" wird."

4 At this point "kommt die Gottheit zur Erfahrung ihrer selbst" (PUV 195).

5 See a similar point in Philosophie. Rückschau und Vorschau am Ende des Jahrhunderts (Frankfurt am Main: Suhrkamp, 1993), 31, where Jonas refers to the "warnenden Wetterleuchten nahender Krise."

6 Jean Greisch's elucidation of the kind of fear that is active in Jonas's work, holds only for the fear of the heuristics of fear (what Jonas calls "Furcht geistiger Art"PV 65) and not for the fear that put Jonas's later philosophical development in motion. Greisch explains that it is "exactement l'inverse de la peur "pathologique." Là où la peur pathologique nous affecte en déclenchant des pensées ou des représentations de panique, dans le cas présent [la peur dans l'heuristique de la peur - EW] nous avons affaire à des pensées (ou des représentations) qui sont à la recherche des affects qui incitent à l'action et à la réflexion," cf. Jean Greisch, "L'amour du monde et le principe responsabilité," in La responsabilité. La condition de notre humanité. (Paris: Editions Autrement, 1994), 72-89, citation p. 75. It is then the 
heuristics of fear that identifies the emotions that testify to the subjective response to the other. However, I want to suggest that there is another fear underlying the heuristics of fear.

7 Jonas's description of his optimism after the Second World War is in line with this idea: "I had returned from the war experience and the nightmare preceding it in an optimistic frame of mind as to the condition of the world about to emerge from the holocaust. Humanity, so it seemed to me, had passed through a crisis which, at its excessive and totally unacceptable price, would still have the effect of a catharsis, at least of a calm after the storm. It was the illusion that crushing one supreme evil, after it had taken its terrible course, would halt the public power of evil in general, if only by sheer exhaustion, for a goodly time to come. Of the better things mankind could now turn to I held good hopes - paradoxically derived from the most frightening technological bequest of the war" (PE xv).

8 Cited from the myth in the version of the notion of God after Auschwitz essay: "Mit dem Erscheinen des Menschen erwachte die Transzendenz zu sich selbst und begleitet hinfort sein Tun mit angehaltenem Atem ... sich ihm [dem Menschen EW] fühlbarmachend, ohne doch in die Dynamik des weltlichen Schauplatzes einzugreifen: Denn könnte es nicht sein, daß das Transzendente durch Widerschein seines Zustandes, wie er flackert mit der schwankenden Bilanz menschlichen Tuns, Licht und Schatten über die menscliche Landschaft wirft?" (PUV 197).

9 Both "Prinzip" and "Grundsatz" can of course be translated by "principle"; my decision to render "Grundsatz" with the somewhat clumsy "foundational rule" is motivated by the need to distinguish clearly between these two German terms. Furthermore, I refrain from rendering "Grundsatz" as "axiom," as Jonas and Herr did in IR, to avoid the impression that this "rule" is to be accepted without justification or that it is supposed by Jonas to be self-evident — Jonas's point is precisely that he intends to provide a justification for it. The translation of the entire citation is my own.

10 Here, as often in PV, "Menschen" (human beings) means "Menschheit” (humanity), since in special cases the "Grundsatz" is not applicable to individuals.

11 I take "der Beginn der Ethik" to be equivalent to "das Ethische" (the ethical), or as I shall call it here, "ethicity."

12 Micha Werner, "Dimensionen der Verantwortung: Ein Werkstattbericht zur Zukunftsethik von Hans Jonas" in Ethik für die Zukunft. Im Diskurs mit Hans Jonas, ed. D. Böhler and I. Hoppe (München: C. H. Beck, 1994), 303-38, here especially 303-12.

13 Werner, 313.

14 An example of the ambiguous statements made by Jonas is found in PV 9, where he describes the historical factors that shift "Verantwortung ins Zentrum der Ethik" (as Kettner rightly points out) - this is said of responsibility in practice, which Jonas himself (as Werner, "Dimensionen der Verantwortung," op. cit. p. 312 correctly quotes) typifies as "Notstandethik," or "Minimalethik" or "Vermeidungsethik"; in other words, responsibility as an "ethics of completion."

15 It might also be useful to recall the wish that Jonas expresses for ethics at the end of PL and to which PV is his answer: "[O]nly an ethics which is grounded in the 
breadth of being ... can have significance in the scheme of things. ... However far, therefore, the ontological quest [in PL - EW] may have carried us outside man, into the general theory of being and of life, it did not move away from ethics, but searched for its possible foundation" (PL 284).

16 The criticism pronounced here against M. Werner also applies (albeit to a lesser degree) to Jean Greisch, the French translator of Das Prinzip Verantwortung, who comments as follows on the use of the word "Prinzip" in the title of the book: apart from the polemics with Bloch, "[I]1 ["the principle" — EW] révèle aussi ses [Jonas's EW] ambitions véritables: faire de l'idée de responsabilité qui, à première vue n'est qu'une vertu parmi d'autres, le fondement même d'une conception inédite de l'éthique."Greisch, “L'amour du monde et le principe responsabilité," op. cit. p. 73. I do not agree that the principle that Jonas defends is a principle only of the new ethics, but of all ethics.

17 If the long duration of the cosmos, as portrayed in Jonas's myth and in his philosophy of the organism, is taken into account, the principle of responsibility could be said to be as old as the self-conscience of God in the human being. Hence the description of this ethics as "a-historical" - it is the same principle of all ethics of humanity.

18 See also the discussion above - in the first article, $\$ 3.2$.

19 Cf. especially PV ch 3, IV, 3, d, entitled "Der Zweckbegriff jenseits der Subjektivität: Sinn des Begriffs."

20 See also PV 156-157, where Jonas speaks of "das Interesse in der Intensität der Selbstzwecke der Lebewesen selber, in denen der Naturzweck zunehmend subjektiv, das heißt dem jeweiligen Vollzieher als der seine zueigen wird.” An intriguing question, which I can only mention here, would be to enquire how Jonas would respond to the question of how non-life-affirming conduct is possible at all.

21 This is argued for in Jonas's Macht oder Ohnmacht der Subjektivität? Das LeibSeele-Problem im Vorfeld des Prinzips Verantwortung. (Frankfurt am Main: Insel Verlag, 1981), but added as Appendix to IR.

22 However, I affirm again that it is not possible to include all of Jonas's statements in my categorization.

23 Jonas's instruction of the primacy of the disaster prognosis, in other words, the essential prudence of the philosophy of responsibility, has attracted frequent criticism because of its alleged conservatism - cf., for instance, Annemarie Gethmann-Siefert's "Ethos und metaphysisches Erbe. Zu den Grundlagen von Hans Jonas' Ethik der Verantwortung," in Philosophie der Gegenwart, Gegenwart der Philosophie, ed. H. Schnädelbach and G. Keil (Hamburg: Junius, 1993), 171-215, especially §2, "Der Konservativismus der Verantwortungsethik," 183ff. The argument underpinning this criticism is that if invention is indeed eliminated by a process of imagination-induced fear, it would in practice imply a tendency toward the maintenance of the status quo. While I do not see anything wrong with the argument on the formal level, the picture does, however, change considerably if Jonas's analysis of the modern world, of the "technological civilization," is taken into consideration. This situation is characterized by technological progress as a "calling" and as an 
omnipresent imperative. If that is the status quo, it would mean that the prudence inscribed in Jonas's heuristics of fear would in effect undermine this ambient imperative of technological progress, which is the status quo; it proposes an unsettling suggestion of a withholding or regional abolition in a context where the continuation of the march of technological progress is the often unexamined rule that governs the state of things. It should therefore be considered seriously whether his position could not at least equally be described as opposing the status quo as revolutionary or liberating.

24 Jonas argues that competence does not mean acting on the basis of theory, amongst other things, on the basis of the example of Lenin (cf. PV 205). It should strike the reader as interesting that Jonas, on this one page, repeats the word "Augenblick" five times, for example, "Theorie aber hatte an dieser Erkenntnis des Augenblicks keinen Anteil" (PV 205). This could well be an idea taken over from the early work of Heidegger - one should consider the latter's reinterpretation of Aristotle's notion of the agent of virtue, who is characterized, amongst other things, by the fact that he or she acts "in knowledge" (eidos): Heidegger associates this knowledgedrivenness of action with circumspection (phronesis $\sim$ ); in other words, acting with "Umsichtigkeit" that is directed at the particular occasion (kairos $\sim$ as Aristotle calls it; Augenblick as Heidegger translates it). See my "Aspects of Technicity in Heidegger's Early Philosophy: Rereading Aristotle's Techné and Hexis," in Research in Phenomenology 38, no. 3 (2008): 317-57 (in particular, 345-6).

25 Cf. also PV 186: "die Möglichkeit, daß es Verantwortung gebe, ist die allem vorausliegende Verantwortung"; PV 92: "Idee von möglichen Täter überhaupt."

26 The term "Ebenbild" is difficult to translate - from Jonas's cryptic notes on it on the last page of PV (and absent from IR), it seems that he borrows it from the notion in Genesis (humans being created in the image of God), but believes that it also has a secular meaning which resides in the idea of humanity that is to be protected by the new ethics of responsibility. Hence my translation of "Ebenbild" as "image [that is not to be violated]."

27 This is in fact what Jonas claims is happening when he speaks of the contemporary technically induced phenomenon of "die wachsende Überlegenheit einer Seite der menschlichen Natur über alle anderen, und unvermeidlich auf ihre Kosten" (PV 32) and of the fact that technology takes a central position in the formation of the "subjektiven menschlichen Zweckleben" (PV 31); in other words, the conduct subject to moral judgment.

28 As has indeed been expressed, amongst others, by Dietrich Böhler, in "What Can the Meaning Be of Responsibility in High-Tech Civilization. A Socratic Discourseethical Perspective," in Discursive modernity, ed. N. Gilje and H. Grimen (Oslo: Universitetsforlag, 2007), 199-229, and 250-5, here 214, and Richard Wolin, Heidegger's Children. Hannah Arendt, Karl Löwith, Hans Jonas, and Herbert Marcuse. (Princeton/Oxford: Princeton University Press, 2001), 123-9.

29 Jonas admits this implicitly, in my opinion, in his reflection on the thought experiment seeking to determine whether a child or a valuable work of art is to be saved from a burning house (PV 188-189 and 400-401). What is interesting in Jonas's 
handling of this dilemma is that neither the "obvious" decision for the life of the child (PV 189) nor the more argued defence of this decision (PV 400-401) is made with the help of the imperative of responsibility and neither could be reconciled with the manner of thinking of Jonas's imperative of responsibility — in fact, there is no trace of the kind of collective, humanity-oriented decision-making that we found in the example of the statesman above. But this strange manner of tackling the dilemma is an eloquent indication of the importance of complementing the principle of responsibility by other ethics. In as far as the Jonasian principle of responsibility is taken into account alone, one should first recognize that this dilemma has no simple answer before proceeding by using the best possible information (the burning house, of course, limits the time available for such an exercise), and then to deploy a heuristics of fear to see what, in each of the two possible courses of action, the outcome would be if the humanity of the collective of humankind is at stake. It may well be that for some ethical agents it is valid to argue and it makes more sense to save the artwork. If such a conclusion bothers us — as it clearly bothered Jonas - it is only because we are already deploying an ethics of responsibility in coordination with other forms of ethics in the light of which it becomes clearly objectionable to consider saving the work of art rather than the child. One could, however, show that it is not absurd at least to consider the way of an ethics of responsibility's concern for humanity, by a slight variation on the thought experiment: suppose we stood in a burning house in 1942 and had to save either a very valuable work of art or Adolf Hitler, trapped in a room - which one would we choose? 